\title{
'It's a pity that they have to choose between French and English': Language ideologies at a Japanese overseas school in Belgium
}

\author{
Yuta Mogi \\ Institute of Education, University College London, UK \\ Article received 17 September 2016, accepted 5 February 2017, final version 26 March 2017 \\ DOI: http://dx.doi.org/10.5565/rev/jtl3.735
}

\begin{abstract}
This article is based on my doctoral research, a qualitative study of a nihonjingakkō in Belgium where students choose either English or French after primary $3^{\text {rd }}$ year. Nihonjingakko is a full-time day school for children of Japanese sojourners. The study investigates the complex language ideologies circulating in the school. Semi-structured interviews were conducted with the school principal and language teachers, and were supplemented by other datasets such as questionnaires and analysis of teaching materials. Drawing on the conceptual framework of imagined communities (Anderson 1991; Kanno \& Norton, 2003), this paper attempts to illuminate the fact that English receives higher language status than French. However, this article will mainly focus on English. To conclude, Japan's school and university entrance examination system can be seen to make students lose interest in learning foreign languages other than English.
\end{abstract}

Keywords: Belgium, English, French, Japan's Overseas School Education, language ideologies

\section{Résumé}

Cet article est basé sur ma recherche doctorale, une étude qualitative d'un nihonjingakkō en Belgique où les étudiants choisissent d'apprendre soit l'anglais soit le français après la 3ème année primaire. Nihonjingakkō est une école de jour à temps plein pour les enfants de séjournants Japonais. L'étude examine les idéologies linguistiques complexes qui circulent dans l'école. Des entretiens semi-structurés ont été menés avec le directeur de l'école et les professeurs de langues, et ont été complétés par d'autres ensembles de données tels que des questionnaires et l'analyse du matériel pédagogique. En s'appuyant sur le cadre conceptuel de "communautés imaginées 》 (Anderson, 1991; Kanno \& Norton, 2003), cet article tente d'éclairer le fait que l'anglais obtient un statut linguistique plus élevé que le français. Cependant, cet article se concentrera principalement sur l'anglais. En conclusion, le système japonais d'examen d'entrée au lycée et à l'université peut être perçu comme faisant perdre aux étudiants de l'intérêt à apprendre et à interagir avec des langues étrangères autres que l'anglais.

Mots-clés: Belgique, anglais, français, éducation scolaire japonais outre-mer, idéologies linguistiques

\section{Resumen}

Este artículo está basado en mi investigación doctoral, la cual es un estudio cualitativo de un nihonjingakkō en Bélgica, donde los estudiantes eligen entre inglés o francés después del tercer año de primaria. Un nihonjingakkō es una 
escuela diurna de tiempo completo para hijos de expatriados japoneses. El estudio investiga las complejas ideologías lingüísticas que circulan en el colegio. Se realizaron entrevistas semi-estructuradas con el director de la escuela y los profesores de idiomas las cuales fueron complementadas con otras bases de datos tales como encuestas y el análisis de los materiales de enseñanza. Mediante el uso del marco conceptual de comunidades imaginadas (Anderson, 1991), este artículo propone que inglés recibe mayor estatus que francés. Sin embargo, el artículo se enfocará principalmente en inglés. Para concluir, se observa que el sistema de evaluación para entrar a la educación secundaria y universitaria en Japón hace que los estudiantes pierdan interés en aprender e interactuar en idiomas extranjeros que no sean el inglés.

Palabras claves: Belga, inglés, francés, educación escolar en el extranjero de Japón, ideologías lingüísticas

\section{概要 \\ 本稿は筆者の進行中である博士課程の研究に基づき、生徒が外国語教育 として小学 3 年生から英語か仏語を選択するベルギーの日本人学校での 質的調査である。日本人学校とは最終的に日本に帰国する日本人駐在員 の子女が通う全日制学校を指す。この研究では、日本人学校における複 合的な言語イデオロギーを調査する。筆者は校長と語学教員との半構 造化インタビューを行い、質問表や教材分析等のデータセットで研究 を補足した。本稿は想像の共同体(Anderson, 1991; Kanno \& Norton, 2003) という概念的枠組みを引用し、英語が仏語より高い言語ステータスを得 ている事実を明らかにすることを試みる。しかしながら、本稿では主に 英語に焦点をあてる。結論として、生徒達の英語以外の外国語の学習と 交流に対する興味を失わせているのは、日本における入試システムであ る可能性が考えられる。 キーワード : ベルギー、英語、フランス語、日本の海外における \\ 学校教育、言語イデオロギー}

\section{Introduction}

My interest in the topic of nihonjingakkō stems from my own upbringing as a Japanese returnee, or kikokushijo. Kikokushijo are children of Japanese expatriates who return to Japan after a prolonged sojourn in a host country (Kanno, 2003). Due to my father's job, I was born in the US. Since my parents expected that my family would eventually return to Japan, I attended both a local school on the weekdays and a Japanese complementary school (hosh $\bar{u} k \bar{o}$ ) every Saturday to improve my Japanese language skills. When I returned to Japan, I was enrolled in a private high school in Tokyo renowned for accepting many kikokushijo. There, I discovered that many students who had come back from non-Anglophone countries had only learned Japanese and English. It seemed sad that they had not used the opportunity to learn the language(s) of the host country(ies) in which they had lived for years. This childhood experience became one of the reasons for selecting language ideologies as the basis 
of my doctoral research. Although many researchers have discussed and raised awareness of Japan's foreign language education which puts an overt emphasis on English (Kanno, 2008; Kubota \& McKay, 2009), there is a dearth of research on Japan's overseas education in a multilingual educational context. In selecting the research site, I chose the nihonjingakkō in Belgium, as Belgium is a country which is widely perceived as the epitome of a multilingual society (Blommaert, 2011)

\section{Research Questions}

Two overarching research questions guided the study on which this paper is based:

1. What language ideologies appear to underpin practices within the nihonjingakko in Belgium?

2. What implications do the language ideologies have for nihonjingakko, kikokushijo, and education in Japan in a multilingual world?

The paper first provides the theoretical framework for the study; it then gives an overview of Japan's foreign language education (mainly English) and Japan's overseas education.

\section{Language Ideology}

Since language ideology is the core of this research, I would like to provide a brief account of my understanding on ideology, in particular, language ideology. My way of viewing ideology is twofold. Firstly, ideology is a socially shared belief and value rooted in the experience and interests of a particular group within society (Schieffelin, Woolard, \& Kroskrity, 1998). These beliefs are treated as 'common sense' and often are not questioned (Gramsci, 1971). Moreover, ideology is closely linked to power, and can be seen to reproduce hierarchies and inequalities within society (Fairclough, 2001). Secondly, I see ideology as multiple and constantly contesting, multilayered construct; it should therefore be examined on more than one level "where ideational, behavioral, and institutional aspects interact and sometimes contract one another" (Darvin \& Norton, 2015, pp. 43-44). Therefore, I use the plural form of the term 'ideologies' in my study to reflect my understanding.

Broadly speaking, 'language ideologies' are ways in which human beings perceive languages, and thus shape the identities and behaviours of language users and language learners (Seargeant, 2009).

\section{Imagined Communities}


Key to this current study is the concept of imagined communities developed by Benedict Anderson (1991), in his discussion of the birth and development of nationalism. Anderson was concerned with spatial imaginings, how people build ties across space through imagination. However, when the notion of imagined communities was applied to the field of applied linguistics and education in the early 2000s (Kanno \& Norton, 2003), the concept was expanded by arguing that people also form imagined ties with the future. In other words, people have imagined communities of which they want to become a member in the future, and these imagined identities influence the learning style and trajectory of learners. Moreover, Kanno (2008) argues that learners are not the only people who imagine their future; parents envision imagined communities for their children, while schools project imagined communities for their students (Dagenais, 2003).

For kikokushijo and their parents, nihonjingakkō serve as imagined communities where students, teachers, and parents interact. The nihonjingakkō in Belgium fosters an atmosphere of intense linguistic and cultural immersion, and when I visited, I felt as if I had stepped into Japan. The school made every effort to ensure that their students maintained a connection to Japan; nihonjingakkō's policies and teaching are shaped by how nihonjingakkō envision future affiliations for their students. The concept of imagined communities is appropriate in this research since it can further develop an understanding of how imagined communities of schools and kikokushijo inform the students' future actions and ambitions regarding language learning.

\section{English education in Japan}

Learning English took on special importance after the Meiji Restoration in 1868 (Butler, 2007), when Japan opened its door to the outside world after repeated foreign pressure. To prevent being colonised by Western powers, Japan embarked upon a process of rapid modernisation which involved emulating the technologically advanced nations of the West. The main objective of learning English was to translate English texts and transmit Western knowledge to modernise Japan (Butler \& Iino, 2005; Koike \& Tanaka, 1995). The government set a high value on writing and reading, rather than on enhancing communication skills (Nishino \& Watanabe, 2008). Following this, grammar and translation-based pedagogy remains dominant in the English language classroom (Friedman, 2016).

However, since the end of the $20^{\text {th }}$ century, faced with continuous criticism from the public (Kikuchi \& Browne, 2009) for not incorporating English teaching for communicative 
purposes, the government has gradually introduced communicative language teaching (CLT) into Japanese primary and secondary education. In 1989, Japan's Ministry of Education (henceforth MEXT) issued a revised national curriculum and declared that the primary goal of Japan's foreign language education was to foster a positive attitude to the international world and develop communicative skills (Yoshida, 2003). In 2003, MEXT announced an Action Plan, which included the proposal of implementing English at primary school level: in 2011, MEXT made English instruction mandatory, beginning with primary 5 at age $10-11$ (Hu \& McKay, 2012; Yoshida, 2012).

The call for a communicative approach was also powerful from Japan's business world, notably the Keidanren, or the Japan Business Federation, whose members come from Japan's multinational corporations (Kubota, 2011). Attributing Japan's long economic recession to its inadequate English skills, Keidanren's aim was to retain Japan's economic global position by promoting nationwide English learning and usage. This is despite the fact that the majority of Japanese businesses are small and medium-sized enterprises (The Small and Medium Enterprise Agency, 2014), which overall do not see English as a business necessity. In other words, Japan's expansion of a "more and earlier" approach to English language learning "can best be understood as part of a trend to align language education policy with neoliberal economic policies" (Sayer, 2015: 53).

Despite MEXT promoting the acquisition of practical conversation skills, the grammar and translation-oriented approach remains prevalent in Japan's formal school system (Hu \& McKay, 2012). This is also reflected in Japan's entrance examination system. Since passing the examination is tied to the examinee's future economic and social wellbeing (Kariya, 2013), both teachers and students conform to a more conventional English language teaching method (Brown \& Yamashita, 1995; Kikuchi, 2006). To characterise this method, which places overt emphasis on grammar and translation, the term juken eigo (English for school entrance examination) is widely used (Yamada, 2013). Within the Japanese school systems, juken eigo dominates classroom practice (O’Donnell, 2005). Preparing students to pass competitive entrance examinations is the priority, and the development of students' communication skills is of secondary importance. As Butler and Iino state, "the history of English language education in Japan can be characterised as alternating between a focus on English for practical purposes and English for entrance examination for higher education" (2005: 27).

It is worth noting that, while foreign languages other than English are rarely taught 
(Kobayashi, 2012), there has recently been an increase in the number of high schools which provide other languages (MEXT, 2016). Despite the fact that Japan is becoming ethnically and linguistically diverse (Kubota \& McKay, 2009), Japanese-English bilingualism is widely assumed to be a practical solution to international communication.

Moreover, the current examination system does little to encourage students to learn languages other than English. Only five foreign languages are offered as part of the Unified University Entrance Exam English, French, German, Korean, and Chinese (Japan National Center for University Entrance Examination, 2015). This reflects MEXT's Course of Study and other policy documents, where 'English' and 'foreign language' are used interchangeably, and the notion that the Japanese public have internalised the equation of “foreign language is English" (Gottlieb, 2008; Yamada, 2015). The complex ideologies surrounding the acquisition of foreign languages other than English is clearly a rich area for research. However, for this paper, I will only focus on the language statuses of English and French as foreign languages in the Belgian nihonjingakkō.

\section{Japan's Overseas Education}

Kikokushijo became a major social and educational issue in the 1960s (Kanno, 2003; Sueda, 2014) when Japanese companies expanded their business overseas and sent employees to various parts of the world. The majority of Japanese living abroad are temporary sojourners who will someday return to Japan. In order for their children not to fall behind academically when they returned to Japan, groups of Japanese expatriate parents started to establish language schools. These groups mainly comprised elite businesspeople and diplomats with high social capital (Goodman, 1990). Their successful lobbying of politicians and the public pushed the Japanese government to fund overseas schools by providing financial aid and sending teachers from Japan (Kanno, 2003).

Apart from local schools, there are four types of educational institutions where Japanese children living overseas are taught: nihonjingakkō, hoshūkō, international schools, and private schools managed by Japanese academic institutions (MEXT, 2015a). Of these, nihonjingakkō and hoshūkō are supported by MEXT and the Ministry of Foreign Affairs, and students can receive education equivalent and equal in standard to that provided in mainstream Japanese schools.

\section{Nihonjingakkō}


Nihonjingakkō is a full-time school: based on the assumption that students will return to Japan at some point, the school strictly follows the Japanese curriculum developed by MEXT. As of 2015 there are 88 nihonjingakkō worldwide, with the majority located in non-Anglophone regions such as Asia (MEXT 2015a; see Graph 1). Every year MEXT (2015b) selects teachers from state and private primary and secondary schools in Japan to be sent to nihonjingakkō; these teachers will return to their former educational institutions in Japan after a few years of teaching at these schools.

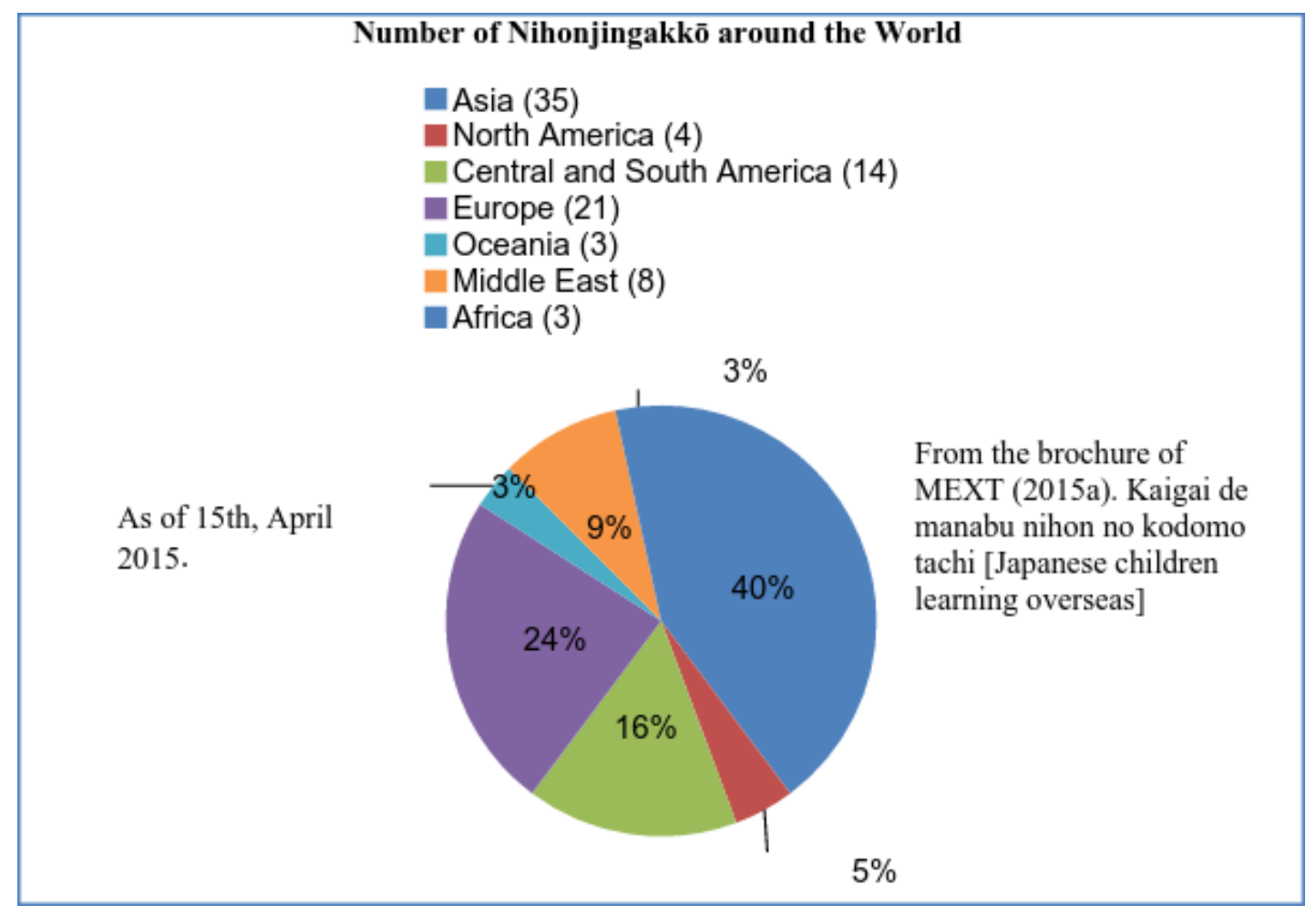

Graph 1: Number of Nihonjingakkō around the world.

\section{The Research Setting}

The school was established in the 1970s by the Japanese Club, and is one of the oldest and largest nihonjingakkō in Europe. Located in a quiet, suburban area of the Flemish-speaking part of Belgium, the school's spacious campus comprises a two-storey building, athletic field, an indoor gymnasium, a library, a music room, and an infirmary. The school also has an official policy of celebrating multilingualism and multiculturalism, reflected in field trips to local museums and class exchange visits with Belgian schools.

Approximately 300 pupils between the ages of 5 and 15 attend the school. Except for 
English and French language classes, students mainly speak Japanese in the school. Yet some students, due to their transient lifestyle, have acquired a fluent level of English before enrolling at the school. After school, some students enjoy activities such as music, or sports. Students' parents are fixed-term sojourners working as employees of Japanese or multinational companies, or Japanese government agencies. Therefore, students return to Japan, or move to other countries within 2-3 years. This life trajectory pattern inevitably impacts upon the students' educational and languages choices, which are however mostly made by parents.

\section{Curriculum}

As noted above, the role of a nihonjingakkō is to offer a Japanese education equivalent to that of Japan. Therefore, Japanese is mandatory from primary 1 to junior high 3, and English is taught from primary 5. However, the school investigated as part of this study also has its own language courses, which are English and French conversation classes taught by foreign language teachers. While French is compulsory for primary $1^{\text {st }}$ and $2^{\text {nd }}$ years, students have to choose either French or English when they enter the primary $3^{\text {rd }}$ year. However, since English is the compulsory subject in junior high, students who choose French are also required to take English classes taught by Japanese teachers. Thus, students who choose English will have additional time to study English.

\begin{tabular}{|l|l|l|l|}
\hline Years & Japanese & English & French \\
\hline Primary 1 to 2 & 7hrs/week & N/A & \\
\hline Primary 3 to 4 & $5.3 \mathrm{hrs} /$ week & $2.5 \mathrm{hrs} /$ week & $2.5 \mathrm{hrs} / \mathrm{heek} /$ week \\
(ages 7-9) & & & \\
\hline Primary 5 to 6 & & & \\
(ages 10-12) & & & \\
\hline
\end{tabular}




\begin{tabular}{|l|l|l|l|}
\hline $\begin{array}{l}\text { Junior High 1 } \\
\text { (ages 12-13) }\end{array}$ & $3.5 \mathrm{hrs} /$ week & $3.7 \mathrm{hrs} /$ week & $3 \mathrm{hrs} /$ week \\
\hline $\begin{array}{l}\text { Junior High 2 } \\
\text { (ages 13-14) }\end{array}$ & $3.5 \mathrm{hrs} /$ week & $3.5 \mathrm{hrs} /$ week & $3 \mathrm{hrs} /$ week \\
\hline Junior High 3 & 2.9hrs/week & $3.8 \mathrm{hrs} /$ week & $2 \mathrm{hrs} /$ week \\
(ages 14-15) & & & \\
\hline
\end{tabular}

Table 2: General Overview of Language Courses as of 2014.

Source: School Handbook

\section{Participants}

The participants for this study are the school principal and 11 language teachers (4 Japanese and 7 non-Japanese), all of whom have a strong educational background with a university or higher level degree. The school principal and all Japanese teachers (2 teachers of Japanese and 2 teachers of English) were recruited by the Japanese Government, and all non-Japanese teachers (3 French teachers, 4 English teachers) are from European countries, including Belgium, Ireland, Spain, and the United Kingdom. The majority of the language teachers had been abroad before teaching at the nihonjingakkō, and are bilingual or multilingual. English was used as a school lingua franca, and I did not witness any language or culture barrier between Japanese and foreign language teachers. Both groups worked together to improve their pedagogy and curriculum.

\section{Methodology}

In this study, I adopted a post-modern approach (Denzin \& Lincoln, 2011; Holliday, 2007). This seemed appropriate given the focus on complex language ideologies apparent in the nihonjingakkō in Belgium, and that the study involves a Japanese diasporic education with which I am familiar. Unlike modernist research, which tends to maintain objectivity by keeping a distance from the research site and participants, a post-modernist perspective privileges a deeper engagement with the research participants. With regard to my study, I considered it neither achievable nor indeed desirable to be a neutral researcher, and 
recognised the need for a methodology that would allow an interpretive approach to its subject matter (Denzin \& Lincoln, 2011). It is necessary to acknowledge that my status as a doctoral student, background as a former returnee, and characteristics such as gender, ethnicity, and age would influence my relationship with the participants and thus the coconstruction of knowledge obtained in the course of this study (see Creese \& Blackledge, 2012).

After gaining research approval from the school in spring 2015, I conducted two fieldwork sessions in summer 2015 and autumn 2015, with each lasting about 2-3 days. The principal source of data was a series of semi-structured face-to-face interviews (Brinkmann \& Kvale, 2015), focus group interviews (Kamberelis \& Dimitriadis, 2013), and e-mail interviews (Gibson, 2010) carried out in English with non-Japanese teachers and in Japanese with Japanese teachers. However, for the interview with a Belgian French teacher who is also fluent in Japanese, I used both English and Japanese. I also gathered data from multiple sources including: questionnaires, classroom observation, and written documents such as the school handbook, textbooks, and the school website. Given the limited space available, the data presented in this article will only come from a semi-structured face-to-face interview with the school principal and two focus group interviews with the Japanese teachers of English and the Belgian teachers of French.

The interview data was transcribed in a "cleaned-up" style (Elliott, 2005), since my major research interest was in the content rather than the form of the verbal data. I excluded all nonverbal cues, suprasegmentals, acoustic sounds, and nonvocal sounds. The content was transcribed in both languages in which I carried out interviews, English and Japanese. I then translated the interview transcripts. These translations were verified by colleagues who have professional training in Japanese-English translation.

The content analysis (Cohen, Manion, \& Morrison, 2011) was employed to identify overlapping themes which emerged from the interviews with participants. These themes were coded and categorised, such as students' languages choice, which shall be discussed in the following section in relation to the research focus of this paper.

\section{Findings and Discussion}

\section{Impact of School Entrance Exam on Language Choice}

In the first session of fieldwork, I held an interview with the principal of the nihonjingakko regarding foreign language education in the school. Although the principal stressed the 
importance of learning the local language of French, he problematised the tendency for the majority of the students to choose English rather than French.

I do not know the ratio. But there are many students who choose English, and there are few students who choose French. The foreign language teachers will probably say the same thing. Students get caught up with school entrance examinations, regardless of their initial intention. When students foresee their future, they think about the school entrance examination. So the language that is not related to school entrance examination, it's a strange story -students choose English rather than French.

The strong influence of the school entrance examination was also reported in a focus group interview conducted with the Japanese teachers of English ${ }^{1}$.

Shinichi: Well, the parents' needs are [for their children to learn] English.

S

akura: Especially when they get older. No matter when you return to Japan in the near future, the students will be taking their high school entrance examination. Although I am not a linguist, from the linguistic point of view, no matter what language you learn, the process of learning the language itself will eventually be very beneficial in learning English. [...]

Shinichi: We have been told by parents. English becomes stronger. For us, you see, we would like students to learn the local language. But there are parents' needs and one of our tasks is to support those needs.

Sakura: Unless Japan's juken eigo changes [English for school entrance examination], the system of the English entrance examination will not change. If there is a major change in the system of English for the school entrance examination, then there would be great change. [...]

Although both Shinichi and Sakura would like students to learn French also, they have to cater to parents' demands for their children to learn English. A focus group interview was held with the French language teachers, Emma and Elena. Here, Emma raised concerns about the dominance of English while acknowledging the fact that the language will be highly important for students after their return to Japan.

Well, [...] it's kind of sad. Of course, we understand that parents want them to learn English for when they go back to Japan. Well it is English which will be important for them. But, I think [...] the three of us all think that it's going to be easier for them if they learn French because they will adapt to the environment easily. [...] I think it's a pity that they have to choose between French and English. They shouldn't [have to] choose. They should [be able to] have both languages.

After Emma had voiced her opinion about having a dual English and French programme, Elena reported that the majority of students choose English believing that it will help them learn juken eigo, which she calls English Japanese.

So most of them choose English because they think that it will be easier to learn the English Japanese. But it's a conversation class. and the content, and the way of 
teaching the English of the Japanese programme is quite different.

Elena is sceptical that selecting English courses taught by non-Japanese teachers will be helpful for students when they return to Japan, since the class focuses on conversation and not on grammar and translation valued in juken eigo.

\section{Interest in Learning French}

Even though English dominance is prevalent in the nihonjingakkō in Belgium, some students do choose French and not English. According to interviews with French language teachers, students who chose French were driven by their integrative motivation (Gardner \& Lambert, 1972); Emma notes:

But most of the time it's the students who are very interested in languages and the culture. Or they do an out-of-school activity such as football, and they want to learn more French to strengthen ties with local people.

Louis, who has taught in the nihonjingakkō for 18 years, gave a further description of students' and parents' increasing interest in learning French by comparing the past and present.

I remember a teacher who worked in the school before me. From the start of the school, many years ago, she worked here for more than 20 years, and, what she said was, at that period, Japanese students thought that French classes were

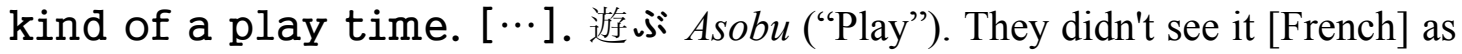
something serious to study. That's really changing. And I think it's coming partly from the parents $[\ldots]$ them being more conscious about the importance of languages, and I think they give that message to their children. And they show it also through coming to us, and asking, "What can I do so my child improves his French?"

\section{Discussion}

This article has presented a snapshot of what makes the majority of students in nihonjingakko choose English instead of French, and indicated why some students chose French. Selected extracts from the interview data illustrate the following points.

First, despite the fact that students and parents are residing in Belgium, most of the students and parents select English. This tendency can be best explained by the strong influence Japan's school entrance examination has on students' and parents' language choice, as learning languages other than English is perceived as unnecessary for this examination.

Second, there are, however, some students who choose French instead of English. This can be attributed to several factors: (1) students are interested in French and the culture 
associated with the language, (2) students would like to further develop their relationship with local people by improving their French, and (3) as a personal fulfilment of learning another language since many students have achieved a high level of English. Moreover, there is a growing interest amongst students and parents in learning French.

In sum, the overemphasis on English within Japan's school entrance examination may deter students from learning foreign languages other than English. In Japan, except for a brief interruption during World War Two ${ }^{21}$, English has been generally embraced as the dominant foreign language beneficial for personal and economic development (Seargeant, 2011). The power and longevity of socio-historically constructed ideologies of English prevalence in the context of Japan's foreign language education may be reproduced in the nihonjingakkō in Belgium.

However, language ideologies are multiple and constantly evolving, influenced by various social and political factors. The discourse in which foreign languages other than English are not widely valued and learnt is yet another discourse that cements the linguistic relations of power. Attention needs to be paid to the social practices that resist powerful discourse of English dominance, as seen in the emerging popularity of French in the nihonjingakkō in Belgium.

A growing interest in learning foreign languages other than English is reported by Sergeant (2009). In interviews held with Japanese participants who studied English at higher education, one student expresses the view that she needs to learn additional languages (French, Italian, and Spanish) since so many Japanese now speak English. Another participant says, "I want to be able to speak Chinese. The reason is simply because the Chinese population will be more dominant in business in future" (2009: 127). It can be said that the value of proficiency in Chinese as linguistic capital (Bourdieu, 1991) is increasing due to the rise of China's economic power (Kanno, 2008; Kubota, 2013).

In order to reinforce this counter ideology, one way is to encourage the government of Japan, specifically MEXT, to add more foreign languages as school subjects in high school, and as a subject for university entrance examination. Yet, there are difficulties in choosing which languages and how to implement a multilingual policy. It is possible that the proposal (JALP, 2014a) and guidelines (JALP, 2014b) given by the Japan Association for Language Policy (JALP) for high school students to choose 1 foreign language other than English from

\footnotetext{
${ }^{1}$ However, scholars (Imura, 2003; Erikawa, 2009) have stated that some mainstream primary and secondary schools taught English even during the wartime.
} 
7 possible choices (Arabic, Chinese, Korean, French, German, Russian, and Spanish) may become a starting point for discussion on Japan's multilingual education reform.

However, this measure may accelerate the linguistic divide that has been documented in studies (Kanno, 2008; Kubota, 2015) interested in "understanding the role played by language in the reproduction of social inequality" (Ricento, 2006: 13). These studies have argued that middle and upper class people have greater access to English language learning and usage. In this respect, promotion of multilingual education may inadvertently widen linguistic stratification, whereby privileged people have greater advantages to learn languages, and in light of the fact that most kikokushijo are children of the new global elite (Vandrick, 2011). This is not to say that those who lack social capital (Bourdieu, 1991) and economic prosperity cannot become multilingual. It may be naive to assume that simply offering languages other than English is in itself likely to foster multilingualism, but that further support to less privileged students must be offered.

\section{Conclusion}

As many scholars have discussed (e.g. Kanno, 2008; Kubota \& McKay, 2009), due to the advance of globalisation, ethnic and linguistic diversity in classrooms in Japan is set to rise (Noguchi \& Fotos, 2001). In most cases, teachers and students of nihonjingakko will eventually return to Japan, and are likely to bring with them new practices which will influence Japan's language education. Their experiences and knowledge will help support both teachers and students in Japan who are facing challenges pertaining to globalisation and transnational migration. Further investigations by academics and policymakers on overseas Japanese educational institutions, in particular in non-Anglophone settings, may provide additional insights for multilingual education policies.

Optimistically speaking, Japan's waning internal market and increasing involvement with foreigners may encourage people to study foreign languages other than English. Increasing economic and cultural ties with neighbouring nations may galvanise Japan to revise its foreign language education policy which overemphasises English. It is therefore important for all those working in the field of language education to recognise and promote increasing interest in multilingualism.

\section{Acknowledgement}

Words are inadequate to express my appreciation to the participants of the study. 


\section{References}

Blommaert, J. (2011). The long language-ideological debate in Belgium. Journal of Multicultural Discourses, 6(3), 241-256.

Bourdieu, P. (1991). Language and symbolic power. (J. B. Thompson, Ed.) Cambridge: Harvard University Press.

Brinkmann, S., \& Kvale, S. (2015). InterViews (1st ed.). Los Angeles: Sage Publications.

Brown, J. D., \& Yamashita, S. O. (1995). English language entrance examinations at Japanese universities: What do we know about them? JALT Journal, 17(1), 7-30.

Butler, Y. G. (2007). Foreign language education at elementary schools in Japan: Searching for solutions amidst growing diversification. Current Issues in Language Planning, $8(2), 129-147$.

Butler, Y. G., \& Iino, M. (2005). Current Japanese reforms in English language education: The 2003 "action plans. Language Policy, 4(1), 25-45.

Cohen, L., Manion, L., \& Morrison, K. (2011). Coding and content analysis. In L. Cohen, L. Manion, \& K. Morrison (Eds.) Research methods in education. (7th ed.) (pp. 559573). London: Routledge.

Creese, A., \& Blackledge, A. (2012). Voice and meaning-making in team ethnography. Anthropology and Education Quarterly, 43(3), 306-324.

Dagenais, D. (2003). Accessing imagined communities through multlilingualism and immersion education. Journal of Language, Identity \& Education, 2(4), 269-283.

Darvin, R., \& Norton, B. (2015). Identity and a model of investment in applied linguistics. Annual Review of Applied Linguistics, 35, 36-56.

Denzin, N. K., \& Lincoln, Y. S. (2011). Introduction: The discipline and practice of qualitative research. In N.K. Denzin \& Y.S. Lincoln (Eds.) The SAGE handbook of qualitative research (4th ed.) (pp. 1-19). Thousand Oaks, CA: Sage.

Elliott, J. (2005). Using narrative in social research: Qualitative and quantitative approaches. Thousand Oaks, CA: Sage.

Erikawa, H. (2009). Nihonjin wa eigo wo dou manandekitaka - Eigo kyouiku no shakai bunkashi [How the Japanese have been learning English - The Sociocultural History of English Education]. Tokyo: Kenkyusha.

Fairclough, N. (2001). Language and power (2nd ed.). London: Longman.

Friedman, J. (2016). English education in the era of Meiji Japan. World Englishes, 35(1), $3-17$.

Gardner, R. C., \& Lambert, W. E. (1972). Attitudes and motivation in secondlanguage learning. Rowley, MA: Newbury House.

Gibson, L. (2010). Using email interviews. $<$ http://www.socialsciences.manchester.ac.uk/realities/resources/toolkits/emailinterviews/09-toolkit-email-interviews.pdf $>$.

Goodman, R. (1990). Japan's “international youth”: The emergence of a new class of schoolchildren. New York: Oxford University Press.

Gottlieb, N. (2008). Japan: language policy and planning in transition. Current Issues in Language Planning, 9(1), 1-68.

Gramsci, A. (1971). Selections from the prison notebooks of Antonio Gramsci. (Q. Hoare \& G. N. Smith, Eds.) London: Lawrence and Wishart.

Holliday, A. (2007). Doing and writing qualitative research. London: Sage.

Hu, G., \& McKay, S. L. (2012). English language education in East Asia: some recent developments. Journal of Multilingual and Multicultural Development, 33(4), 345362 . 
Imura, M. (2003). Nihon no eigo kyouiku 200 nen [200 years history of English education in Japan]. Tokyo: Taishukan Shoten.

JALP. (2014a). Global jinzai no tame no gaikokugo kyouiku seisaku ni kansuru teigenKoutou gakko ni okeru fukusuu gaikokugo hisshuuka ni mukete - [Proposal for Multilingual Education for Cultivating Global Human Resources]. Retrieved from: http://jalp.jp/wp/wpcontent/uploads/2014/12/c62f1c06c99e0f810541b5c1a3235f721.p df

JALP. (2014b). Daini no gaikokugo no gakushuu shidou yoryou (An) [A plan for course of study for second language]. Retrieved from: http://jalp.jp/wp/wpcontent/uploads/2014/12/2113e2f1af669bbbdd37258571a2d2f8.pdf

Japan National Center for University Entrance Examination. (2015). Heisei 28 nendo daigaku nyugakusha senbatsu daigaku nyushi center shiken jisshi yoko [Overview of Nationwide Unified University Entrance Exams Examination in 2016]. Available at: http://www.dnc.ac.jp

Kamberelis, G., \& Dimitriadis, G. (2013). Focus groups: From structured interviews to collective conversations. New York: Routledge.

Kanno, Y. (2003). Negotiating bilingual and bicultural identities: Japanese returnees betwixt two worlds. Mahwah, New Jersey: Lawrence Erlbaum Associates.

Kanno, Y. (2008). Language and education in Japan: Unequal access to bilingualism. Basingstoke: Palgrave Macmillan.

Kanno, Y., \& Norton, B. (2003). Imagined communities and educational possibilities: Introduction. Journal of Language, Identity \& Education, 2(4), 241-249.

Kariya, T. (2013). Education reform and social class in Japan: The emerging incentive divide (M. Burtscher, Trans.). New York: Routledge. (Original work published 2001)

Kikuchi, K. (2006). Revisiting English entrance examinations at Japanese universities after a decade. JALT Journal, 28(1), 77-96.

Kikuchi, K., \& Browne, C. (2009). English educational policy for high schools in Japan: Ideals vs. reality. RELC Journal, 40(2), 172-191.

Kobayashi, Y. (2012). Global English capital and the domestic economy: the case of Japan from the 1970s to early 2012. Journal of Multilingual and Multicultural Development, 34(1), 1-13.

Koike, I., \& Tanaka, H. (1995). English in foreign langauge education policy in Japan: Toward the twenty-first century. World Englishes, 14(1), 13-25.

Kubota, R. (2011). Questioning linguistic instrumentalism: English, neoliberalism, and language tests in Japan. Linguistics and Education, 22(3), 248-260.

Kubota, R. (2013). "Language is only a tool": Japanese expatriates working in China and implications for language teaching. Multilingual Education, 3(1), 4.

Kubota, R. (2015). Neoliberal paradoxes of language learning: xenophobia and international communication. Journal of Multilingual and Multicultural Development, 1-14.

Kubota, R., \& McKay, S. (2009). Globalization and language learning in rural Japan: The role of English in the local linguistic ecology. TESOL Quarterly, 43(4), 593-619.

MEXT. (2015a). Kaigai de manabu nihon no kodomo tachi [Japanese children studying overseas] [Brochure].

MEXT. (2015b). Nihonjingakkō/Hoshujyugyoko e no kyouin haken no gaiyo [Overview of Teachers Dispatched to Nihonjingakkō/Hoshujyugyoko]. Retrieved from: http://www.mext.go.jp/a_menu/shotou/clarinet/002/004/001.htm

MEXT. (2016). Eigo igai no gaikokugo no kamoku wo kaisetsu shiteiru gakko no jyoko ni tsuite Heisei nijuroku nen gogatsu tsuitachi genzai [Schools providing non-English foreign languages as school subject]. Retrieved from: 
http:/www.mext.go.jp/b menu/shingi/chukyo/chukyo3/058/siryo/ icsFiles/afieldfile /2016/05/25/1371098_1.pdf

Nishino, T., \& Watanabe, M. (2008). Communication-oriented policies versus classroom realities in Japan. TESOL Quarterly, 42(1), 133-138.

Noguchi, M. G., \& Fotos, S. (Eds.) (2001). Studies in Japanese bilingualism. Clevedon: Multilingual Matters.

O'Donnell, K. (2005). Japanese secondary English teachers: Negotiation of educational roles in the face of curricular reform. Language, Culture and Curriculum, 18(3), 300-315.

Ricento, T. (2006). Language policy: Theory and practice-an introduction. In T. Ricento (Ed.) An introduction to language policy: Theory and method (pp. 10-23). Malden, MA: Blackwell Publishing.

Sayer, P. (2015). "More and earlier"': Neoliberalism and primary English education in Mexican schools. L2 Journal, 7(3), 40-56.

Schieffelin, B. B., Woolard, K, A., \& Kroskrity, P. V. (Eds.) (1998). Language ideologies: Practice and theory. New York: Oxford University Press.

Seargeant, P. (2009). The idea of English in Japan: Ideology and the evolution of a global language. Tonawanda, New York: Multilingual Matters.

Seargeant, P. (2011). English in Japan in the era of globalization. New York: Palgrave Macmillan.

Sueda, K. (2014). Negotiating multiple identities: Shame and pride among Japanese returnees. Singapore: Springer.

The Small and Medium Enterprise Agency. (2014). Todofuken, Daitoshibetsu Kigyo-suu, Jyoyo Koyohsha-suu, Jyugyoinsha-suu (Min-ei, Hi-ichiji Sangyo) [Number of Enterprises, Full-time Workers, and Employees By Prefecture and Major Cities in Japan (Private and Non-Primary Industries)] Retrieved from: http://www.chusho.meti.go.jp/koukai/chousa/chu_kigyocnt/150129kigyou.pdf

Vandrick, S. (2011). Students of the new global elite. TESOL Quarterly, 45(1), 160-69.

Yamada, M. (2013). Diversity matters: Japan's domestic diversity and the role of English language teaching. Critical Inquiry in Language Studies, 10(3), 215-241.

Yamada, M. (2015). The role of English teaching in modern Japan: Diversity and multiculturalism through English language education in a globalized era. New York: Routledge.

Yoshida, K. (2003). Language education policy in Japan: The problem of espoused objectives versus practice. The Modern Language Journal, 87(2), 290-292.

Yoshida, K. (2012). Issues in the transition of English education from elementary schools to secondary schools. In B. Spolsky \& Y. Moon (Eds.) Primary school English-language Education in Asia: FrompPolicy to practice (pp. 23-37). New York: Routledge.

\footnotetext{
${ }^{1}$ All names used are pseudonyms.

${ }^{2}$ However, scholars (Imura, 2003; Erikawa, 2009) have stated that some mainstream primary and secondary schools taught English even during the wartime.
}

\section{Author's information:}

Yuta Mogi is a PhD student in the Department of Culture, Communication, and Media at University College London, Institute of Education. His research interests include language ideologies, multilingual education, and Japan's overseas education. Yuta is a part-time lecturer at the Center for English as a Lingua Franca at Tamagawa University in Tokyo, Japan.

Email: yutamogi13@gmail.com

To cite this article: 
Mogi, Y. (2017). 'It's a pity that they have to choose between French and English': Language ideologies at a Japanese overseas school in Belgium. Bellaterra Journal of Teaching \& Learning Language \& Literature, 10(2), 59-76. DOI: http://dx.doi.org/10.5565/rev/jt13.735 